\title{
Praktikalitas Multimedia Interaktif Dilengkapi Educational Games pada Materi Archaebacteria dan Eubacteria untuk Siswa Kelas X
}

\author{
Rahmadhani Fitri $^{1^{*}}$, Laila Kurnia Sari ${ }^{2}$ \\ 1,2 Jurusan Biologi, FMIPA, Universitas Negeri Padang, Padang, Indonesia \\ Pengiriman: 3 Mei 2019; Diterima: 2 Oktober 2019; Publikasi Oktober 2019
}

\begin{abstract}
Based on the result of observation and interview, many students were not interested in following the learning because the learning media is less varied. The appropiate learning media could help students learn to master the lesson materials. The solution was by using interactive multimedia was completed by educational games which can be used whenever they want for involving their study. The Biology teacher and the students in SMA Negeri 8 was trained to use interactive multimedia was completed by educational games in biology learning. This training was evaluated through practicality instrument. Data analyzed using descriptive statistical analysis. Based on the results of data analysis obtained the value of practicality is $79,54 \%$ by teacher with practice category and by student equal to $89,60 \%$ with very practice category.
\end{abstract}

Keywords: Practicality, Interactive Mutimedia, Educational Games.

\begin{abstract}
ABSTRAK. Berdasarkan hasil observasi dan wawancara, banyak siswa kurang berminat mengikuti pembelajaran karena media yang kurang bervariasi. Media pembelajaran yang tepat dapat membantu siswa belajar menguasai materi pelajaran. Salah satu solusinya adalah dengan menggunakan multimedia interaktif yang dilengkapi dengan game edukasi yang dapat digunakan kapan saja mereka mau untuk mempelajari materi pelajaran. Multimedia interaktif yang dilengkapi dengan game edukasi dalam pembelajaran biologi diujicobakan pada guru Biologi dan siswa di SMA Negeri 8. Uji coba ini dievaluasi melalui instrumen kepraktisan. Data dianalisis menggunakan analisis statistik deskriptif. Berdasarkan hasil analisis data diperoleh nilai kepraktisan dengan kategori praktis yaitu dengan nilai 79,54\% oleh guru dan 89,60\% oleh siswa.
\end{abstract}

Kata Kunci: Praktikalitas, Multimedia Interaktif, Educational Games.

*Penulis Korespondensi.

Alamat surel: rahmadhanifitri@fmipa.unp.ac.id 


\section{PENDAHULUAN}

Salah satu upaya seorang guru dalam membantu siswa belajar adalah mengembangkan media pembelajaran yang sesuai. Adanya media pembelajaran dapat membantu guru menyampaikan pesan pembelajaran serta membantu siswa menerima pesan pembelajaran dengan mudah. Menurut Iriantara (2014) menyatakan bahwa media pembelajaran dipandang sebagai fasilitator pembelajaran yang efisien.

Berdasarkan hasil observasi diketahui bahwa guru kurang memvariasikan media pembelajaran. Guru menggunakan media pembelajaran berupa Lembar Kerja Siswa dan sesekali menggunakan media Power Point. Akan tetapi, penggunaan Lembar Kerja Siswa ternyata membuat siswa kurang tertarik mengikuti proses pembelajaran sehingga pada akhirnya siswa tidak dapat memahami materi pelajaran.

Pada hakikatnya, seorang guru dituntut untuk dapat mengembangkan media pembelajaran yang bervariasi. Peraturan Menteri Pendidikan Nasional (Permendikas) Nomor 16 Tahun 2007 menyatakan bahwa guru sebagai pendidik profesional harus mengembangkan materi pembelajaran yang diampu secara kreatif. Mengembangkan media pembelajaran yang sesuai dengan situasi, kebutuhan siswa, serta perkembangan kemampuan siswa adalah hal yang perlu diperhatikan dalam mengembangkan media pembelajaran (BNSP, 2007).

Perlunya guru sesekali memvariasikan media pembelajaran guna membangkitkan semangat siswa untuk belajar sehingga pembelajaran menjadi lebih menyenangkan. Pembelajaran yang menyenangkan adalah jika materi pelajaran dapat dikuasai oleh siswa dengan cara yang menyenangkan seperti belajar sambil bermain. Sebagaimana yang disampaikan oleh Taufiq dkk. (2014) menyatakan bahwa siswa yang senang dalam mengikuti proses pembelajaran dapat meningkatkan kemandirian belajarnya. Hal ini juga didukung oleh pendapat Bjoener dan Hansen (2010) menyatakan bahwa siswa akan telibat aktif dalam pembelajarn menggunakan educational games. Belajar sambil bermain yang dapat diterapkan dalam pembelajaran adalah dengan menggunakan media pembelajaran berupa multimedia interaktif dilengkapi educational games yang mengandung unsur pendidikan. Hasil analisis siswa melalui angket diperoleh informasi bahwa 92\% siswa senang bermain game.

Game edukasi atau educational game merupakan salah satu cara membantu siswa belajar dengan cara yang menyenangkan. Seperti yang disampaikan oleh Fitri dan Yogica (2018) menyatakan bahwa game edukasi adalah salah satu jenis media pembelajaran yang digunakan untuk memberikan pengajaran melalui media yang unik dan menarik. Educational games yang digunakan sebagai media pembelajaran dapat membuat siswa termotivasi untuk berpikir dalam menyelesaikan tantangan yang ada di dalam game. Educational games dirancang dengan struktur yang memungkinkan siswa melakukan kegiatan menyelidiki sehingga termotivasi oleh rasa ingin tahu yang tinggi. Noemi dan Maximo (2014) menyatakan bahwa educational games memiliki potensi yang bagus untuk pengajaran karena memiliki efek yang positif dalam proses pembelajaran. Satyaprakasha (2014) juga menyampaikan bahwa pembelajaran dengan menggunakan multimedia interaktif secara signifikan dapat meningkatkan pemahaman dalam pembelajaran biologi.

Educational games yang dimuat dalam multimedia interaktif tentunya menambah semangat dan interaksi siswa dalam menggunakan media pembelajaran karena memiliki tampilan, nuansa, dan gameplay yang menarik. Cairncross dan mannion (2014) menyatakan bahwa interaksi dalam multimedia interaktif membantu siswa dalam pembelajaran karena siswa dapat memilih pilihannya sendiri dengan mengklik variasi menu dan tombol yang digunakan. Penggunaan multimedia interaktif dilengkapi educational games memberikan beberapa keuntungan, yaitu:

a. bersifat dinamis sehingga tidak membosankan,

b. memberikan pilihan menu beragam sehingga siswa memiliki kesempatan untuk memilih menu pilihan yang disukainya,

c. memiliki keanekaragaman materi yang dapat dipahami siswa, dan

d. Umpan balik dapat diberikan secara beragam sehingga dapat meningkatkan motivasi siswa untuk belajar (Sanjaya, 2012).

Berdasarkan hasil penelitian sebelumnya, Priliandika (2017) dan Ananda (2017) bahwa multimedia interaktif bermuatan games dapat membantu siswa belajar secara mandiri, merangsang daya pikir, dan membantu siswa memahami konsep pelajaran dengan baik sesuai dengan cara belajarnya masing-masing.

Penelitian sebelumnya sudah dilakukan untuk mengetahui kelayakan penggunaan multimedia interaktif dilengkapi educational games dengan hasil bahwa produk yang dihasilkan telah valid (Sari dan Fitri, 2019). Hasil penelitian menyatakan bahwa media tersebut layak digunakan dalam proses pembelajaran dan tentunya perlu dilakukan uji coba untuk mengetahui kepraktisan dan kemudahan 
penggunaan serta manfaat dari penggunaan multimedia interaktif dilengkapi educational games.

\begin{tabular}{|c|l|c|c|}
\hline & $\begin{array}{l}\text { Waktu } \\
\text { pembelajaran }\end{array}$ & & \\
\hline 3 & $\begin{array}{l}\text { Daya Tarik } \\
\text { dan Manfaat }\end{array}$ & 88,63 & Praktis \\
\hline & Rata-rata & $\mathbf{7 9 , 5 4}$ & Praktis \\
\hline
\end{tabular}

\section{METODE PENELITIAN}

Jenis penelitian yang dilakukan adalah penelitian pengembangan (Research and Development). Model pengembangan yang digunakan adalah model pengembangan 4-D yang terdiri dari tahap pendifinisian (define), tahap perancangan (design), tahap pengembangan (develop), dan tahap penyebaran (disseminate). Pada penelitian ini peneliti hanya melakukan tahap develop khususnya pada tahap uji praktikalitas produk oleh guru dan siswa. Instrumen yang digunakan berupa lembar praktikalitas oleh guru dan siswa. Data hasil uji praktikalitas dianalisis menggunakan teknik analisis deskriptif dengan merujuk pada kriteria yang ditampilkan pada Tabel 1 berikut.

Tabel 1. Kriteria Tingkat Praktikalitas

\begin{tabular}{|c|c|}
\hline Persentase (\%) & Kategori \\
\hline $90-100$ & Sangat Praktis \\
\hline $75-89$ & Praktis \\
\hline $60-74$ & Cukup Praktis \\
\hline $50-59$ & Tidak Praktis \\
\hline $50<$ & Sangat Tidak Praktis \\
\hline
\end{tabular}

Sumber: Modifikasi dari Purwanto (2012)

\section{HASIL DAN PEMBAHASAN}

Proses uji praktikalitas multimedia interaktif dilengkapi educational games dilakukan oleh seorang guru biologi dan 20 orang siswa SMA Negeri 8 Padang. Komponen penilaian uji praktikalitas terdiri dari kemudahan penggunaan, efisiensi waktu pembelajaran, serta daya tarik dan manfaat multimedia interaktif dilengkapi educational games. Hasil uji praktikalitas multimedia interaktif dilengkai educational games oleh guru dan siswa disajikan pada Tabel 2 dan 3 berikut.

Tabel 2.Hasil Analisis Uji Praktikalitas Multimedia Interaktif dilengkapi Educational Games oleh Guru

\begin{tabular}{|c|l|c|l|}
\hline No. & $\begin{array}{c}\text { Aspek } \\
\text { Penilaian }\end{array}$ & $\begin{array}{c}\text { Rerata } \\
\text { Nilai } \\
(\mathbf{\%})\end{array}$ & Kategori \\
\hline 1 & $\begin{array}{l}\text { Kemudahan } \\
\text { Penggunaan }\end{array}$ & 75,00 & Praktis \\
\hline 2 & Efisiensi & 75,00 & Praktis \\
\hline
\end{tabular}

Tabel 3. Hasil Analisis Uji Praktikalitas Mutimedia interaktif dilengkapi Educational Games oleh Siswa

\begin{tabular}{|c|c|c|c|}
\hline No. & $\begin{array}{c}\text { Aspek } \\
\text { Penilaian }\end{array}$ & $\begin{array}{c}\text { Rerata } \\
\text { Nilai } \\
(\%)\end{array}$ & Kategori \\
\hline 1 & $\begin{array}{l}\text { Kemudahan } \\
\text { Penggunaan }\end{array}$ & 88,39 & Praktis \\
\hline 2 & $\begin{array}{l}\text { Efisiensi } \\
\text { Waktu } \\
\text { pembelajaran }\end{array}$ & 88,75 & Praktis \\
\hline 3 & $\begin{array}{l}\text { Daya Tarik } \\
\text { dan Manfaat }\end{array}$ & 91,66 & Sangat Praktis \\
\hline \multicolumn{2}{|r|}{ Rata-rata } & 89,60 & Praktis \\
\hline
\end{tabular}

Berdasarkan hasil analisis penilaian uji praktikalitas multimedia interaktif dilengkapi educational games diketahui bahwa kategori nilai produk tersebut adalah praktis dengan nilai $79,54 \%$ oleh guru dan $89,60 \%$ oleh siswa. Berdasarkan data tersebut diketahui bahwa multimedia interaktif dilengkapi educational games yang diuji cobakan dinilai praktis sebagai media pembelajaran karena telah sesuai dengan komponen penilaian yang sudah ditentukan. Seperti yang disampaikan oleh Krisnawati (2012) bahwa produk multimedia dinyatakan praktis karena sudah memenuhi penilaian pada instrumen yang sudah disusun.

Instrument yang praktis ini juga dikarenakan media dapat mempermudah guru dalam menyampaikan materi pelajaran dan sebagai salah satu variasi penggunaan media selain LKS yang ada di sekolah. Hal ini juga disampaikan oleh Zakirman dan Hidayati (2017) bahwa media pembelajaran yang praktis adalah media yang dapat membantu guru dalam memberikan informasi yang luas, menjelaskan materi lebih baik, mengaktifkan dan menumbuhkan percaya diri siswa.

Berdasarkan data penilitian diketahui bahwa kemudahan penggunaan berada pada kategori praktis oleh guru dan siswa. Artinya, multimedia interaktif dilengkapi educational games menyajikan petunjuk penggunaan yang mudah dipahami baik oleh guru maupun siswa serta tombol dan keseluruhan multimedia interaktif dapat dioperasikan dengan mudah sehingga multimedia interaktif dilengkapi educational games secara keseluruhan dapat membantu belajar siswa menjadi lebih menarik. Seperti yang disampaikan Fathiyati dan Utami 
(2012) bahwa kepraktisan penggunaan media pembelajaran sangat memabantu siswa karena siswa menjadi lebih tertarik dan bersemangat dalam mempelajari materi.

Data hasil penelitian juga menunjukkan bahwa efisiensi waktu pembelajaran dalam menggunakan multimedia interaktif dilengkapi educational games berada pada kategori praktis oleh guru dan siswa. Berdasarkan penilaian tersebut diketahui bahwa waktu pembelajaran lebih efisien karena memberikan kemudahan bagi guru untuk menyampaikan materi pembelajaran dan mampu mengurangi beban guru untuk menjelaskan materi secara berulang-ulang. Selain itu, multimedia interaktif dilengkapi educational games yang dikembangkan membantu siswa belajar sesuai dengan kecepatan belajarnya masing-masing. Seperti yang disampaikan oleh Fitriza dkk. (2018) bahwa kepraktisan media pembelajaran dapat digunakan secara berulangulang.

Hasil uji coba untuk melihat kepraktisan media pembelajran pada kategori penilaian aspek daya tarik dan manfaat memiliki criteria praktis oleh furu dan sangat praktis oleh siswa. Hal ini dapat diartikan bahwa guru dan siswa tertarik mempelajari materi karena tampilan dari multimedia yang menarik. Seperti yang disampaikan oleh Fitri dkk. (2014) bahwa siswa tertarik mempelajari LKS karena memiliki tampilan menarik. Warna-warna yang dipilih untuk teks, gambar, dan latar belakang LKS me-rupakan warna-warna kontras yang mendukung pembelajaran. Senam dkk. (2008) juga menyampaikan bahwa wujud LKS yang menarik, disertai gambar dan ilustrasi di dalamnya, akan membuat siswa lebih senang mempelajarinya.

\section{KESIMPULAN DAN SARAN}

Berdasarkan hasil penelitian yang telah dilakukan dapat disimpulkan bahwa penggunaan multimedia interaktif dilengkapi educational games memiliki kepraktisan yang baik dari segi kemudahan penggunaan, efisiensi waktu pembelajaran, serta daya tarik dan manfaat. Berdasarkan penelitian yang telah dilakukan, disarankan pada praktisi pendidikan khususnya guru menjadikan produk ini sebagai salah satu alternatif dan variasi media yang dapat digunakan untuk menyampaikan materi pelajaran dalam proses pembelajaran

\section{DAFTAR PUSTAKA}

Ananda, R. P. (2017). "Pengembangan Multimedia Interaktif disertai Games Duel Otak pada Materi Ekosistem untuk Peserta Didik Kelas X MIA SMA”.
Bekala Ilmiah Bidang Biologi, Vol. 1, No. 2: 261268.

BNSP. (2007). Peraturan Menteri Pendidikan Nasional Republik Indonesia Nomor 16 Tahun 2007 tentang Standar Kualifikasi Akademik dan Kompetensi Guru. Jakarta: BSNP.

Bjoener, T. dan C. B. Hansen. (2010) "Design an educational Games: Desin Principles from a Holistic Perspective". International Journal of Learning, Vol. 17, No. 10: 279-290.

Cairncross, S. dan M. Mannion. (2001). "Interactive Multimedia and Learning: Realizing the Benefits". Innovations in Education and Teaching International, Vol. 38, No. 2: 156-164.

Priliandhika, V. (2017). "Pengembangan Multimedia Interaktif Bermuatan Games Tebak Kata (MI-GTK) pada Materi Sistem Ekskresi Manusia untuk Peserta Didik Kelas XI SMA". Berkala Ilmiah Bidang Biologi, Vol. 1, No. 2: 295-305.

Fathiyati, R. dan R. P. Utami. (2012). "Pengembangan Media Pembelajaran Biologi Berbasis Flash sebagai Sumber Belajar bagi Siswa SMA/MA Kelas XI Semester 2 Materi Pokok Sistem Reproduksi Manusia". Prosiding Seminar Biologi, Vol. 9, No. 1: 211-217.

Fitri, R., R. Sumarmin, dan Y. Ahda. (2014). "Pengembangan Lembar Kerja Siswa Biologi Berorientasi Pendekatan Kontekstual pada Materi Pewarisan Sifat Untuk Kelas IX". Jurnal Penelitian Pendidikan, Vol. 5, No. 1: 55-64.

Fitri, R. dan R. Yogica. (2018). "Validitas Game Edukasi Klasifikasi Tumbuhan Berbasis Permainan Koa sebagai Media Pembelajaran Biologi" Jurnal Pedagogi Hayati, Vol. 2, No. 2: 25-30.

Fitriza, Z., Iswendi, Iryandi, dan F. Q. 'Aini. (2018). "Praktikalitas Penggunaan Media Sosial Pembelajaran Edmodo untuk Program Remedial dan Forum Diskusi Guru". Jurnal Eksakta Pendidikan (JEP), Vol. 2, No. 1: 78-84.

Iriantara, Y. (2014). Komunikasi Pembelajaran: Interaksi, Komunikatif, dan Edukatif dalam Kelas. Bandung: Remaja Rosdakarya.

Krisnawati, T. (2014). "Pengembangan Multimedia Interaktif Pembelajaran untuk Mata Pelajaran Biologi di SMA". Jurnal Ilmiah Guru "COPE”, No. 02: 1-7. 
Noemi, P. dan S. H. Maximo. (2014). "Educational Games For Learning". Journal of Educational, Vol. 2, No. 3: 230-238.

Satyaprakasha, C. V. dan Y. Sudhanshu. (2014). "Effect of Multi Media Teaching on Achievement in Biology". International Journal of Education and Psychological Research, Vol. 3, No. 1: 41- 45.

Senam, R. Arianingrum, Rr. L. Permatasari, dan Suharto. (2008). Efektivitas Pembelajaran Kimia untuk Siswa SMA Kelas XI dengan Menggunakan LKS Kimia Berbasis Life Skill. Didaktika, Volume 9, Nomor 3: 280-290.

Taufiq, M., N. R. Dewi, dan A. Widiyatmoko. (2014). "Pengembangan Media Pembelajaran IPA Terpadu Berkarakter Peduli Lingkungan Tema 'Konservasi' Berpendekatan Science Edutainment'. Jurnal Pendidikan IPA Indonesia, Vol. 3, No. 2: 140-1.

Zakirman dan Hidayati. (2017). Praktikalitas Media Video dan Animasi dalam Pembelajaran Fisika di SMP. Jurnal Ilmiah Pendidikan Fisika Al-Biruni, Vol. 06 No. 1: 85-93 